\title{
Lumbar Spinal Stiffness Overshadows Polyethylene Wear: A Modern Explanation for Late Dislocation in Total Hip Arthroplasty
}

\author{
Omar A Behery, Jonathan M Vigdorchik, Aaron J Buckland and William Macaulay* \\ Department of Orthopedic Surgery, NYU Langone Orthopedic Hospital, USA
}

Submission: May 22, 2018; Published: May 30, 2018

*Corresponding author: William Macaulay, Professor, Department of Orthopedic Surgery, Medical Director, International Patient Services, NYU Langone Health, 246 East 20th Street, Suite 103, New York, NY 10003, Tel: 646-356-9410; Email: william.macaulay@nyumc.org

\section{Introduction}

Instability or dislocation after total hip arthroplasty (THA) is a dreaded complication, occurring with rates ranging from $0.3 \%$ to $10 \%$ [1-4], and is the most common reason for revision surgery [5]. Risk factors for instability following THA include patientspecific factors such as non-compliance, neuromuscular or cognitive disorders, as well as surgical considerations including approach [6], soft tissue tension, component size; positioning, implant choice and polyethylene wear [7]. Traditionally, it is thought that the THA dislocation occurs in a bimodal distribution, based on timing after surgery (early and late). Early dislocations, which occur within the first two years following THA, are more common than late dislocations, and are more commonly attributed to component malposition [8], patient non-compliance (drug abuse or dementia) or neurocognitive disability (Parkinson Disease), or conditions affecting soft tissue quality and tension including soft tissue repair, rheumatoid arthritis and a vascular necrosis [9-11]. Late THA dislocations, which usually occur many years after THA, have been largely attributed to (based on our classic adult reconstruction teaching dogma) eccentric polyethylene wear [12].

There is evidence that the rates of both early and late dislocations have declined substantially in the past decade [11] which has coincided with improvements in bearing surfaces, more frequent use of larger diameter femoral heads and improvements in surgical technique including posterior softtissue capsular repair $[7,13,14]$. One improvement in particular is the increasing use of highly cross-linked polyethylene liners, which have demonstrated very low linear and volumetric wear rates at long-term follow-up [15], even in conjunction with the increasing use of larger diameter metal heads [16]. These low wear rates have been shown to result in greater implant survival, less osteolysis and revision for aseptic loosening compared with the use of conventional polyethylene over the long-term [17-20]. Although there is no definitive evidence, it is likely that this low wear rate also contributes to the observed decrease in late THA dislocations given the improved survivorship of highly crosslinked polyethylene over conventional polyethylene. Moreover, with the superior wear characteristics of highly cross-linked polyethylene liners, the use of larger femoral head diameters $(>=36 \mathrm{~mm})$, which are associated with a lower dislocation risk, has become a widely practical option $[21,22]$.

While polyethylene wear has been the traditionally highlighted factor in late THA instability, there is increasing evidence and emphasis on the association between THA dislocation and changes in a patient's sagittal lumbopelvic alignment. Spino-pelvic kinematics, sagittal alignment, and spinal balance are prone to change over time in the setting of progressive degenerative changes of the lumbar spine, or acutely in the setting of a lumbar spinal fusion. These changes have a profound effect on the dynamics between the lumbar spine and the pelvis during different postural positions (eg. from sitting to standing). Biomechanically, lumbar spondylosis typically results in decreased lumbar lordosis, and posterior pelvic tilt, causing degenerative flat back deformity [23].

The effect of the resulting pelvic retroversion is an increase in acetabular cup anteversion and abduction. The opposite is true following long segment spinal fusion for spinal deformity which results in increased lordosis, anterior pelvic tilt and reduced acetabular anteversion [24]. In lumbar hyperlordosis, sacral slope and anterior pelvic tilt increase, resulting in decreased acetabular version and inclination. Coupled with a fused and therefore stiff spine, this results in increased risk of posterior hip dislocation [25,26]. For each of these scenarios, one degree of posterior pelvic tilt has been shown to increase acetabular anteversion by 0.74 degrees [27]. These relationships are also dynamically related to postural changes from standing to sitting. Sitting decreases pelvic tilt and sacral slope, and therefore increases acetabular retroversion and abduction [28]. In a flexible spine, particularly in patients with a high pelvic incidence, the pelvis tilts posteriorly in sitting. These results in 
increased acetabular anteversion, improved posterior coverage of the femoral head, and therefore are protective against posterior dislocation. However, in a stiff, degenerative spine, or in the case of lumbar fusion, posterior pelvic tilt is limited, and therefore the risk of prosthetic hip instability is higher due to anterior femoroacetabular impingement and reduced posterior coverage.

Increased risk of THA instability has been demonstrated in multiple studies with patient cohorts having degenerative lumbar spinal disease [29-32], with an estimated rate of 3-7\% in those with lumbar fusion [33-35]. In particular, patients experiencing total hip arthroplasty dislocation were noted to have more fixed spinopelvic alignment between standing and sitting, with fewer changes in lumbar lordosis and pelvic tilt. Although several of these studies have noted THA dislocations in early followup, particularly in the setting of lumbar fusion, it is likely that late THA dislocations are increasingly seen in individuals who develop lumbar spondylosis and stiffness over long-term followup from their primary THA [25]. More longitudinal studies examining late THA dislocations and changes in lumbopelvic alignment over time are needed to validate this inference. Over the past two decades, as late THA dislocation rates improved secondary to improved bearing surfaces and less polyethylene wear, the attention is shifting towards THA dislocations associated with progressive degenerative lumbar spinal disease. There is no currently available data to compare the risk of late dislocation from highly cross-linked polyethylene wear to that from lumbar spinal disease, but it is likely that the modern trend is shifting to the latter carrying a higher risk.

The clinical implications of these changes in trends of late THA dislocations warrant attention. With lumbar spinal stiffness and alignment becoming a more important factor in predicting the risk of total hip dislocation, there is an increasing need to appropriately evaluate a patient's lumbar sagittal alignment and flexibility prior to undergoing THA. The use of sitting and standing imaging has been growing in popularity to evaluate spinopelvic parameters pre-operatively and can guide the surgeon to planning cup position and implant choice, to decrease dislocation risk.

\section{Conflicts of Interest}

There are no conflicts of interest or disclosures relevant this work.

\section{References}

1. Lee PC, Shih CH, Chen WJ, Tu YK, Tai CL (1999) Early polyethylene wear and osteolysis in cementless total hip arthroplasty: the influence of femoral head size and polyethylene thickness. J Arthroplasty 14(8): 976-981.

2. Padgett DE, Warashina H (2004) The unstable total hip replacement. Clin Orthop Relat Res 420: 72-79.

3. Parvizi J, Picinic E, Sharkey PF (2008) Revision total hip arthroplasty for instability: surgical techniques and principles. J Bone Joint Surg Am 90(5): 1134-1142.
4. Ritter MA (1976) Dislocation and subluxation of the total hip replacement. Clinical orthopaedics and related research 121: 92-94.

5. Bozic KJ, Kurtz SM, Lau E, Ong K, Vail TP, et al. (2009) The epidemiology of revision total hip arthroplasty in the United States. J Bone Joint Surg Am 91(1): 128-133.

6. Kwon MS, Kuskowski M, Mulhall KJ, Macaulay W, Brown TE, et al. (2006) Does surgical approach affect total hip arthroplasty dislocation rates? Clinical orthopaedics and related research 447: 34-38.

7. Soong M, Rubash HE, Macaulay W (2004) Dislocation after total hip arthroplasty. The Journal of the American Academy of Orthopaedic Surgeons 12(5): 314-321.

8. Danoff JR, Bobman JT, Cunn G, Murtaugh T, Gorroochurn P, et al. (2016) Redefining the Acetabular Component Safe Zone for Posterior Approach Total Hip Arthroplasty. J Arthroplasty 31(2): 506-511.

9. Gausden EB, Parhar HS, Popper JE, Sculco PK, Rush BNM (2018) Risk Factors for Early Dislocation Following Primary Elective Total Hip Arthroplasty. The Journal of arthroplasty 33(5): 1567-1571.

10. Suh KT, Park BG, Choi YJ (2004) A posterior approach to primary total hip arthroplasty with soft tissue repair. Clinical orthopaedics and related research 418: 162-167.

11. Malkani AL, Ong KL, Lau E, Kurtz SM, Justice BJ, et al. (2010) Earlyand late-term dislocation risk after primary hip arthroplasty in the Medicare population. J Arthroplasty 25(6 Suppl): 21-25.

12. Parvizi J, Wade FA, Rapuri V, Springer BD, Berry DJ, et al. (2006) Revision hip arthroplasty for late instability secondary to polyethylene wear. Clinical orthopaedics and related research 447: 66-69.

13. Mahoney CR, Pellicci PM (2003) Complications in primary total hip arthroplasty: avoidance and management of dislocations. Instr Course Lect 52: 247-255.

14. DeWal H, Su E, DiCesare PE (2003) Instability following total hip arthroplasty. Am J Orthop (Belle Mead NJ) 32(8): 377-382.

15. Garvin KL, White TC, Dusad A, Hartman CW, Martell J (2015) Low wear rates seen in THAs with highly crosslinked polyethylene at 9 to 14 years in patients younger than age 50 years. Clinical orthopaedics and related research 473(12): 3829-3835.

16. Lachiewicz PF, O'Dell JA, Martell JM (2018) Large Metal Heads and Highly Cross-Linked Polyethylene Provide Low Wear and Complications at 5-13 Years. J Arthroplasty pii: S0883-5403(18)30211-0.

17. Howie DW, Holubowycz OT, Callary SA (2016) The Wear Rate of Highly Cross-Linked Polyethylene in Total Hip Replacement Is Not Increased by Large Articulations: A Randomized Controlled Trial. J Bone Joint Surg Am 98(21): 1786-1793.

18. Devane PA, Horne JG, Ashmore A, Mutimer J, Kim W, et al. (2017) Highly Cross-Linked Polyethylene Reduces Wear and Revision Rates in Total Hip Arthroplasty: A 10-Year Double-Blinded Randomized Controlled Trial. J Bone Joint Surg Am 99(20): 1703-1714.

19. Thomas GE, Simpson DJ, Mehmood S, Taylor A, McLardy-Smith P, et al. (2011) The seven-year wear of highly cross-linked polyethylene in total hip arthroplasty: a double-blind, randomized controlled trial using radiostereometric analysis. The Journal of bone and joint surgery American volume 93(8): 716-722.

20. Glyn-Jones S, Thomas GE, Garfjeld-Roberts P, Gundle R, Taylor A, et al. (2015) The John Charnley Award: Highly crosslinked polyethylene in total hip arthroplasty decreases long-term wear: a double-blind randomized trial. Clinical orthopaedics and related research 473(2): 432-438.

21. Skeels MD, Berend KR, Lombardi AV (2009) The dislocator, early and late: the role of large heads. Orthopedics 32(9). 
22. Howie DW, Holubowycz OT, Middleton R, Large Articulation Study Group (2012) Large femoral heads decrease the incidence of dislocation after total hip arthroplasty: a randomized controlled trial. J Bone Joint Surg Am 94(12): 1095-1102.

23. Jackson RP, McManus AC (1994) Radiographic analysis of sagittal plane alignment and balance in standing volunteers and patients with low back pain matched for age, sex, and size. A prospective controlled clinical study. Spine 19(14): 1611-1618.

24. Buckland AJ, Vigdorchik J, Schwab FJ, Errico TJ, Lafage R, et al. (2015) Acetabular Anteversion Changes Due to Spinal Deformity Correction: Bridging the Gap between Hip and Spine Surgeons. J Bone Joint Surg Am 97(23): 1913

25. Mudrick CA, Melvin JS, Springer BD (2015) Late posterior hip instability after lumbar spinopelvic fusion. Arthroplasty today 1(2): 25-29.

26. Maratt JD, Esposito CI, McLawhorn AS, Jerabek SA, Padgett DE, et al. (2015) Pelvic tilt in patients undergoing total hip arthroplasty: when does it matter? J Arthroplasty 30(3): 387-391.

27. Wan Z, Malik A, Jaramaz B, Chao L, Dorr LD (2009) Imaging and navigation measurement of acetabular component position in THA Clin Orthop Relat Res 467(1): 32-42.

28. Lazennec JY, Brusson A, Rousseau MA (2013) Lumbar-pelvic-femoral balance on sitting and standing lateral radiographs. Orthopaedics \& traumatology, surgery \& research: OTSR 99(1): S87-S103.

29. Blizzard DJ, Sheets CZ, Seyler TM, Penrose CT, Klement MR, et al.
(2017) The Impact of Lumbar Spine Disease and Deformity on Total Hip Arthroplasty Outcomes. Orthopedics 40(3): e520-e525.

30. Esposito CI, Carroll KM, Sculco PK, Padgett DE, Jerabek SA, et al. (2018) Total Hip Arthroplasty Patients With Fixed Spinopelvic Alignment Are at Higher Risk of Hip Dislocation. J Arthroplasty 33(5): 1449-1454.

31. Sultan AA, Khlopas A, Piuzzi NS, Chughtai M, Sodhi N, et al. (2018) The Impact of Spino-Pelvic Alignment on Total Hip Arthroplasty Outcomes: A Critical Analysis of Current Evidence. The Journal of arthroplasty 33(5): 1606-1616.

32. DelSole EM, Vigdorchik JM, Schwarzkopf R, Errico TJ, Buckland AJ (2017) Total Hip Arthroplasty in the Spinal Deformity Population: Does Degree of Sagittal Deformity Affect Rates of Safe Zone Placement, Instability, or Revision? J Arthroplasty 32(6): 1910-1917.

33. Malkani AL, Garber AT, Ong KL, Dimar JR, Baykal D, et al. (2018) Total Hip Arthroplasty in Patients With Previous Lumbar Fusion Surgery: Are There More Dislocations and Revisions? J Arthroplasty 33(4): 1189-1193.

34. Buckland AJ, Puvanesarajah V, Vigdorchik J, Schwarzkopf R, Jain A, et al. (2017) Dislocation of a primary total hip arthroplasty is more common in patients with a lumbar spinal fusion. The bone \& joint journal 99B(5): 585-591.

35. Perfetti DC, Schwarzkopf R, Buckland AJ, Paulino CB, Vigdorchik JM (2017) Prosthetic Dislocation and Revision After Primary Total Hip Arthroplasty in Lumbar Fusion Patients: A Propensity Score MatchedPair Analysis. J Arthroplasty 32(5): 1635-1640.

\section{Your next submission with Juniper Publishers will reach you the below assets}

- Quality Editorial service

- Swift Peer Review

- Reprints availability

- E-prints Service

- Manuscript Podcast for convenient understanding

- Global attainment for your research

- Manuscript accessibility in different formats

( Pdf, E-pub, Full Text, Audio)

- Unceasing customer service

Track the below URL for one-step submission https://juniperpublishers.com/online-submission.php 